\title{
Direct Hydrogenation and Hydrotreating of Neat Vegetal Oil into Renewable Diesel Using Alumina Binder with Zeolite
}

\author{
SHANMUGAM PALANISAMY*, KANNAN KANDASAMY
}

School of Chemical and Food Science, Kongu Engineering College, Erode-638 060, India

\begin{abstract}
Hydrodeoxygenation of vegetal oil and methyl oleate studied using Pt and Pd supported with alumina-beta-zeolite $\left(\gamma-\mathrm{Al}_{2} \mathrm{O}_{3}-\mathrm{H}-\beta\right)$ and comparing its performance with $\mathrm{NiMo} / \gamma-\mathrm{Al}_{2} \mathrm{O}_{3}$ and $\mathrm{Pd} / \mathrm{C}$ in a semi-batch reactor, at $300-340^{\circ} \mathrm{C}$ and $2.0 \mathrm{MPa}$. This study has used Pd and Pt on $\mathrm{H}-\beta$ zeolites with alumina binder as extrudate and it examines over triglycerides hydrogenolysis. $P d / C$ showed higher rate of deoxygenation and the selectivity of $\mathrm{C}_{18} / \mathrm{C}_{17}$ was higher for $\mathrm{NiMo}-\mathrm{S} / \gamma-\mathrm{Al}_{2} \mathrm{O}_{3}$ and $\mathrm{PdPt} / \gamma-\mathrm{Al}_{2} \mathrm{O}_{3}-\mathrm{H}-\beta$. $\mathrm{PdPt} / \gamma-\mathrm{Al}_{2} \mathrm{O}_{3}-\mathrm{H}-\mathrm{\beta}$ enhanced the hydrogenation and hydrogenolysis, while conversion and yield in deoxygenation and decomposition has reached identicical performance as $\mathrm{NiMo}-\mathrm{S} / \gamma-\mathrm{Al}_{2} \mathrm{O}_{3}$ catalytic deoxygenation process. Both the thermal decomposition and the hydrogenation of unsaturated triglycerides were mainly affected by $\mathrm{H}_{2}$ partial pressure. Transition metals like $\mathrm{Pd}$ and $\mathrm{Pt}$ on $\mathrm{H}-\beta$ and alumina binder ratio of 40:60 wt\% showed effective hydrodeoxygenation of vegetal oil without substituting sulfur feed.
\end{abstract}

Keywords: Hydroprocessing, Vegetal oil, Alumina, Carbon, Zeolite

\section{Introduction}

In the present scenario, few refineries are involved in producing biomass based diesel-like fuel, named as renewable diesel, to replace the conventional one [1-5]. In the last two decades, raw vegetal oils, animal fats and algal oils had been converted into renewable diesel by catalytic hydrotreatment techniques [5-15]. With that, three main methods, such as hydrogenolysis, catalytic cracking and thermal cracking were deeply investigated. Hydrogenolysis produces long straight-chain hydrocarbon with a high cetane index, while cracking produces straight-chain hydrocarbon with by-products of lighter hydrocarbons and aromatics which were in the range of gasoline and fuel gas [16].

During triglycerides hydrogenolysis, catalytic hydrodeoxygenation (HDO) produce n-octadecane $\left(\mathrm{C}_{18}\right)$ in organic liquid products (OLP). Also, decarboxylation (DCO) (by-product as $\mathrm{CO}_{2}$ ) and decarbonylation (DCA) (by-product as $\mathrm{CO}$ ) are the side reactions, which produce n-heptadecane $\left(\mathrm{C}_{17}\right)$ [3-11, 15-18]. This study have been collectively involved in HDO, DCA and DCO of triglyceride in the presence of $\mathrm{H}_{2}$ and named as hydroprocessing of vegetable oil [3-11]. At the hydroprocessing condition, (i.e.) between operating temperature of 300 to $400^{\circ} \mathrm{C}$ and pressure of 1.0 to $10.0 \mathrm{MPa}$, solid catalyst on HDO was extensively studied in the literature [15-18]. Here, OLP may also contain traces of saturated and unsaturated hydrocarbons of acid, ester, alcohol, aldehyde, ketone in aromatic and aliphatic structure.

Recently, number of studies in the literature have investigated with catalytic effect over sulfide or non-sulfide form of mono- or bi-metals over the metal oxides like $\mathrm{Al}_{2} \mathrm{O}_{3}, \mathrm{SiO}_{2}$, activated carbon, alumino-silicates and zeolite [14-24]. In few studies, activated carbon has been investigated over methyl or ethyl esters, which produced low pour-point property of diesel-like fuel, but had higher reaction rate on DCA than HDO [15-17].

High catalytic activity, high turnover frequency of active sites, chemical stability and a known quantity of catalysts requirement are mainly successful with the use of sulfiding transition metals. Here, substituting sulphur in feed for co-processing diesel and fatty acids makes additional operating cost [22, 23]. However, sulphur on mono- or bi-metallic transition metals on the support metal-phosphide and metal-carbide were extensively investigated in hydroprocessing conditions [21,25].

*email: shapal.chem@kongu.edu 
If sulphur substituent concentration in the feed increases, the sulphur bounded bi-metallic transition metals (M-S) showed stable and high activity. In the case of absence of sulphur in the feed, active metal sites can be deactivated at a faster rate because of feed leaches $\mathrm{M}-\mathrm{S}$ on active site by water formation. Sulfide catalyst has higher activity on metal-phosphide and metal-carbides support, but it was expensive due to the preparation and transformation of active catalyst $[19,28]$. Similarly, Langmuir IV-isotherm adsorption type Ni-PTA/ $/ \mathrm{Al}_{2} \mathrm{O}_{3}$ had given better yield and selectivity [24]. The presence of selective alumina as support had higher product selectivity and less cracking as compared to $\mathrm{SiO}_{2}$ [23-26]. So, economically viable catalyst without sulphur-bound are extensively searched recent years.

In the search of sulphur-free catalyst, there were possibilities to use alumino-silicates or zeolites, such as Zeolite Socony Mobil (ZSM), mesoporous zeolite (SBA), Hydrogen-Beta (H- $\beta$ ), Y-type (H-Y), Silicoaluminophosphate (SAPO) and Mobil Composition Materials (MCM) in catalytic hydrotreatment of vegetal oil [18]. These materials with significant metal loads, are mainly involved in HDO and branching of hydrocarbon chains (they reduce cold flow plugging point) [25]. The recent study shows that substituting transition metals in lattice structures has increased the reactivity of catalyst, with slow deactivation at mild and moderate temperatures [24, 28]. In estimating the selectivity of HDO in compared to DCO and DCA products, the metals like Ni, Pd and Pt are more suitable [26, 29-31]. Like $\gamma-\mathrm{Al}_{2} \mathrm{O}_{3}$, the study mainly reveals that the zeolite-type metal oxides could be thermally stable, enhancing branching in hydrocarbon and increasing HDO yield. In this context, zeolite-type catalyst might be suitable for catalytic hydrotreatment of raw vegetal oil. The utilization of excess $\mathrm{H}_{2}$ enables the slow deactivation and coking, where continuous $\mathrm{H}_{2} \mathrm{O}$ production, as a by-product in $\mathrm{HDO}$, reduces the leach over the active metals on catalyst surface and make way for $\mathrm{C}-\mathrm{O}$ bond breaking in triglycerides [30, 31]. And also, absences of $\mathrm{H}_{2}$ in thermal cracking of vegetable oil had produced esters, which reduce the reaction rate and yield [26].

Excluding mono-metallic catalyst, the recent study conducted with bi-metallic catalyst involved shorter reaction time and better selectivity [26, 29]. In this series, selecting two transition metals (bimetals) with positive reduction potential on catalyst surface can effectively increase the HDO selectivity and activity. Sulphur-free metal catalysts with the reduced state can avoid sulphur contamination in the hydroprocessing product, but enhances DCA and DCO mechanism. Though less consumption of $\mathrm{H}_{2}$ in DCO and DCA were theoretically economically compared to HDO, sulphur-free catalyst can adapt and does not contaminate the product by sulphur leaching [26]. Pt can emphasis the reduction of hydrocarbon and $\mathrm{Pd}$ can increase the capability of $\mathrm{H}$-proton donor potential due to the strong interaction of Pd atom with the zeolite atoms. Both Pt and Pd are recommended to be used as a sulphur-free catalyst for investigating hydrotreatment of vegetal oil [26].

This work investigates the performance of sulphur-free bi-metallic catalysts, such as $\mathrm{Pt}$ and $\mathrm{Pd}$ on alumina zeolite $\left(\mathrm{Pt}-\mathrm{Pd} / \gamma-\mathrm{Al}_{2} \mathrm{O}_{3}-\mathrm{H}-\beta\right) \mathrm{NiMo} / \gamma-\mathrm{Al}_{2} \mathrm{O}_{3}$ and $\mathrm{Pd} / \mathrm{C}$, at $320^{\circ} \mathrm{C}$ and $2.0 \mathrm{MPa}$, in a semi-batch process. The study focus on HDO and DCA mechanism in OLP and the composition of fuel gas in the gas outlet.

\section{Materials and methods}

\subsection{Materials}

The pure triglyceride as refined from sunflower oil (SVO), purchased in a retail shop, contains no free fatty acids. The methyl oleate ( $98 \%$ from Sigma Aldrich) as model FAME compounds, n-dodecane (99\% from Sigma-Aldrich) as solvent and n-tetradecane (99\% from Sigma-Aldrich) as an internal standard of the sample were used. The catalyst used for the investigation was $\mathrm{NiMo} / \mathrm{Al}_{2} \mathrm{O}_{3}(\mathrm{Criterion}$ catalysts), its commercial name being Trilobe HDN-60, $5 \mathrm{wt} \% \mathrm{Pd}$ on activated Carbon (lot number: 205680 from Sigma-Aldrich) as named $\mathrm{Pd} / \mathrm{C}$, and Beta zeolite in $\mathrm{H}$-form, named as $\mathrm{H}-\beta$ (Product no: CP811C-300 from International zeolite corp. USA) with $\mathrm{SiO}_{2} / \mathrm{Al}_{2} \mathrm{O}_{3}$ mole ratio of 300 and $0.05 \mathrm{wt} \%$ of $\mathrm{Na}_{2} \mathrm{O}$. High purity of Boehmite Alumina Hydrates (as trade name disperal) was purchased from Sasol, Germany and $\mathrm{Pt}\left(\mathrm{NH}_{3}\right)_{4} \mathrm{Cl}_{2}$ solution was purchased from Sigma-Aldrich. Boehmite Alumina Hydrates is used for the extrusion and $\mathrm{Pt}\left(\mathrm{NH}_{3}\right)_{4} \mathrm{Cl}_{2}$ solution was used as $\mathrm{Pt}$ load on the zeolite. 


\subsection{Catalyst activation}

The $\mathrm{NiMo} / \mathrm{Al}_{2} \mathrm{O}_{3}$ contains 2-3\% Ni, 12-14 \% Mo and 83-86\% $\gamma-\mathrm{Al}_{2} \mathrm{O}_{3}$ support, extrudes at the sieve range of 10-30 DIN (aperture $~ 0.2-0.6 \mathrm{~mm}$ ), for investigation of both sulphide and sulphide-free form of hydroprocessing catalyst. With reference to the previous studies, the sulphide form of $\mathrm{NiMo} / \gamma-\mathrm{Al}_{2} \mathrm{O}_{3}$ (NiMo-S), calcined at $400^{\circ} \mathrm{C}$, and in-situ sulphidation was carried out with $10 \%$ by volume of $\mathrm{S}$ in $\mathrm{H}_{2} \mathrm{~S}$ at $200 \mathrm{~mL} / \mathrm{min}$, for $3 \mathrm{~h}$, in the trickle-bed reactor [6, 11] and a sulphide-free form of $\mathrm{NiMo} / \gamma-\mathrm{Al}_{2} \mathrm{O}_{3}$ (NiMo) carried in-situ activated in $\mathrm{H}_{2}$, at $400^{\circ} \mathrm{C}$. Similarly, the $\mathrm{Pd} / \mathrm{C}$ was activated with $\mathrm{H}_{2}$ after drying in an oven at $110^{\circ} \mathrm{C}$ for $4 \mathrm{~h}$. The catalysts were kept under an $\mathrm{N}_{2}$ atmosphere to prevent from oxidation.

$\mathrm{H}-\beta$ and disperal (boehmite) were blended in a ratio of 40:60 wt $\%$, and the hydrated blend was extruded in $1 / 32^{\prime \prime}$ and dried at $110^{\circ} \mathrm{C}$, for $5 \mathrm{~h}$. After calcination at $300^{\circ} \mathrm{C}$ for $4 \mathrm{~h}, 0.5 \mathrm{wt} \%$ of $\mathrm{Pd}$ and 0.5 wt\% of Pt with respect to weight of support material (dry basis) are loaded on the extruder by wet impregnation method using $\mathrm{Pt}\left(\mathrm{NO}_{3}\right)_{2} \cdot 2 \mathrm{H}_{2} \mathrm{O}$ and $\mathrm{Pd}\left(\mathrm{NO}_{3}\right)_{2}$ solution. Finally, the zeolite loaded with $\mathrm{Pd}$ and $\mathrm{Pt}\left(\mathrm{Pt}-\mathrm{Pd} / \gamma-\mathrm{Al}_{2} \mathrm{O}_{3}-\mathrm{H}-\beta\right)$ was calcined at $400^{\circ} \mathrm{C}$ for $6 \mathrm{~h}$. The Pt-Pd/ $\gamma-\mathrm{Al}_{2} \mathrm{O}_{3}-\mathrm{H}-\beta$ was crushed and sieved in 10-30 DIN, and $\mathrm{H}_{2}$ in-situ activation performed as like $\mathrm{Pd} / \mathrm{C}$ and NiMo catalysts.

\subsection{Reactor}

The semi-batch reactor consists of a stainless steel vessel of $300 \mathrm{~mL}$ capacity. The reactor was connected with both inlet and outlet gas line. It consists of an eight-microprocessor based process controller with an integrated part to the thermocouple, heating mantle and magnetic stirrer [6]. After the catalyst activation, $1 \mathrm{~g}$ of catalyst taken in the vessel with a $150 \mathrm{~mL}$ solution containing $20 \mathrm{wt} \%$ of SVO in $\mathrm{n}$-dodecane and $3 \mathrm{~g}$ of $\mathrm{n}$-tetradecane as an internal standard [6]. The experiments were carried out from 320 and $340^{\circ} \mathrm{C}$ at $2 \mathrm{MPa}$, with the same stirring speed. Sampling point was connected at a gas outlet connection and an average of $1 \mathrm{~mL}$ of liquid sample (OLP) was extracted and stored in the $6^{\circ} \mathrm{C}$ cooler for analysis.

\subsection{Physico-chemical characterization}

The specific area and pore volume of the samples were analysed using Tristar 3000 automated Gas Adsorption Analyzer, measured by $\mathrm{N}_{2}$ physisorption isotherms at $-195^{\circ} \mathrm{C}$. Before the analysis, $1 \mathrm{~g}$ sample of catalyst was thermally dried in a vacuum chamber, at $90^{\circ} \mathrm{C}$ for $4 \mathrm{~h}$, in $\mathrm{N}_{2}$ gas flow and used for specific surface area and pore-volume measurements.

The spent catalyst was refined for $22 \mathrm{~h}$ to extract the solvent, using $\mathrm{m}$-xylene in the Soxhlet apparatus. The refined spent catalyst was dried in a vacuum dryer at $125^{\circ} \mathrm{C}$ under $\mathrm{N}_{2}$, followed by the analysis of coke deposition by BELAB AB, Sweden, using an ASTM D5291 standard test method (Leco CHN-600 instrument).

Simple distillation of $500 \mathrm{~mL}$ of OLP sample distilled under $\mathrm{N}_{2}$ atmosphere $(100 \mathrm{~mL} / \mathrm{min})$, at two desirable cut-off temperatures, i.e. $100{ }^{\circ} \mathrm{C}$ to remove water molecules in distillate and $200^{\circ} \mathrm{C}$ to remove $\mathrm{n}$-dodecane and lighter hydrocarbons in distillate and rest as residue. This distillation was performed to identify the water molecules formation and elemental analysis of OLP residues.

The Spectrum One from Perkin-Elmer Fourier Transform Infrared Spectroscopy (FTIR) was used to analyses OLP samples at room temperature. OLP sample is placed between two high purity $\mathrm{NaCl}$ salt plates (pair of demountable cell in $4 \mathrm{~mm}$ thickness) with care for ensuring that no air bubbles appeared and the reading noted for mid-infrared ranges from $4000 \mathrm{~cm}^{-1}$ to $400 \mathrm{~cm}^{-1}$ [7].

Based on simulated distillation methods of ASTM D2887 standard, OLP samples ( $5 \mu \mathrm{L})$ has injected in Varian 3400 Gas chromatography (GC), equipped with a packed column (10\% silicon OV-101, 80100 mesh, $1 \mathrm{~m} \times 1 / 8$ " $\times 2.00 \mathrm{~mm}$ ) and a Flame Ionization Detector (FID) and Varian 4279 integrator are used for data computing [7]. With the injector and detector temperature of $300^{\circ} \mathrm{C}$, the column oven temperature raised from 40 to $325^{\circ} \mathrm{C}$, at a heating ramp of $18^{\circ} \mathrm{C} / \mathrm{min}$ and the final temperature has been maintained for $10 \mathrm{~min}$.

The outlet gas from the reactor was analysed using the Clarus $500 \mathrm{GC}$ online, connected with 600 link switch controllers, with the signal integrated to receive data. Gas analyser consists of inlet and outlet 
sampling valves, actuated by $\mathrm{N}_{2}$ gas on $0.4 \mathrm{MPa}$, which analyses $\mathrm{CO}, \mathrm{CO}_{2}, \mathrm{CH}_{4}$ and $\mathrm{H}_{2}$ at Thermal Conductivity Detector (TCD) and hydrocarbons in FID $6,7,11]$. Elemental analyses in OLP such as C, $\mathrm{H}$ and $\mathrm{O}$ under ASTM D5291 standard test method are performed at Karlshamn Kraft AB, Sweden. The traces of $\mathrm{S}$, metals and salts are exempted in the analytical test [7].

Bruker 600 NMR spectrometer, containing a $5 \mathrm{~mm}$ diffusion probe, was used to analyse under 300 $\mathrm{MHz}$ for ${ }^{1} \mathrm{H}$. Pretreatment of SVO carried in vortex mix of $0.2 \mathrm{~g}$ in 400 microliter of deuterated chloroform, and the sample has placed in a 5-mm diameter ultra-precision.

\section{Results and discussions}

The experimental investigation has been performed for $\mathrm{Pd} / \mathrm{C}$, bi-metallic catalysts like NiMo on alumina and PtPd on the alumina-zeolite.

Table 1. Characterization of zeolite molecular size and extruded catalyst, determined by $\mathrm{N}_{2}$ sorption, using the BET method

\begin{tabular}{|c|c|c|c|c|c|c|}
\hline Material & $\begin{array}{c}\text { Surface } \\
\text { area } \\
\left(\mathbf{m}^{2} / \mathbf{g}\right)\end{array}$ & $\begin{array}{c}\text { Pore } \\
\text { volume } \\
\left(\mathrm{cm}^{3} / \mathrm{g}\right) \\
\end{array}$ & $\begin{array}{l}\text { Average pore } \\
\text { width }(\AA)\end{array}$ & $\begin{array}{c}\text { Adsorption } \\
\text { average pore } \\
\text { diameter }^{\text {a }}(\AA)\end{array}$ & $\begin{array}{c}\text { Desorption } \\
\text { average pore } \\
\text { diameterb }(\AA)^{\circ}\end{array}$ & $\begin{array}{r}\text { Coke db } \\
\text { (ASTM } \\
\text { D5373) } \\
\end{array}$ \\
\hline $\mathrm{Pd} / \mathrm{C}$ & 935.7 & 0.22 & 31.8 & 51.0 & 48.4 & $* *$ \\
\hline $\mathrm{NiMo} / \mathrm{Al}_{2} \mathrm{O}_{3}$ & 157.6 & 0.34 & 87.0 & 75.6 & 64.2 & 0.09 \\
\hline H- $\beta$ & 383.1 & 0.32 & 33.6 & 53.4 & 49.3 & $* *$ \\
\hline Extruded H- $\beta$ & 236.0 & 0.24 & 40.8 & 54.2 & 48.7 & 0.1 \\
\hline Spent-NiMo-S & 54.5 & 0.12 & 89.5 & 69.6 & 51.1 & 2.1 \\
\hline $\begin{array}{c}\text { Spent-Pt-Pd/ } \gamma- \\
\mathrm{Al}_{2} \mathrm{O}_{3}-\mathrm{H}-\beta\end{array}$ & 140.8 & 0.14 & 38.5 & 44.3 & 40.2 & 2.0 \\
\hline
\end{tabular}

${ }^{a}$ Estimated from the adsorption branch of the isothermal $\mathrm{N}_{2}$ sorption, using the $\mathrm{BJH}$ method.

${ }^{b}$ Estimated from the desorption branch of the isothermal $\mathrm{N}_{2}$ sorption, using the $\mathrm{BJH}$ method.

${ }^{c}$ Analyzed by BELAB AB, Sweden, ASTM D 5291 standard test method. db=dry basis.

The pore size of the investigated catalysts, as shown in Figure 1 and Table 1, appears at the range between $50 \AA$ and $80 \AA \AA$. Mainly, NiMo has an average adsorption pore diameter of $75.65 \AA$ and $\mathrm{Pt}-\mathrm{Pd} /$ $\gamma-\mathrm{Al}_{2} \mathrm{O}_{3}-\mathrm{H}-\beta$ had $54.24 \AA$. $\mathrm{Pd} / \mathrm{C}$ had an average adsorption pore diameter of $51.03 \AA$ A. However, $\mathrm{Pd} / \mathrm{C}$ in HDO might have a DCA/DCO mechanism with intermediates of oleate or stearaldehyde, and HDO can be enhanced with active sites using a fresh $\mathrm{H}_{2}$ supply. But, coke deposition over active sites can harm the activity and performance of catalyst life-span. On this NiMo regeneration ability, coke deposition over catalyst can deteriorate pore mouth shrinking and decreases the surface area. The spent NiMo-S average adsorption pore diameter was $64.2 \AA$, and the surface area was $54.5 \mathrm{~m}^{2} / \mathrm{g}$, whereas fresh NiMo-S had $157.6 \mathrm{~m}^{2} / \mathrm{g}$. The trend of $\mathrm{N}_{2}$ absorption and desorption appeared as Langmuir type IV isotherms for both fresh (Figure 1) and spent catalyst, but the quantity of adsorption diminished with the coke deposition. The total pore volume for adsorption of fresh and spent catalyst reduced from 0.34 $\mathrm{cm}^{3} / \mathrm{g}$ to $0.12 \mathrm{~cm}^{3} / \mathrm{g}$. Hence, the coke deposits might be involved in the rupture of S-metal and further formation of hydrogen sulphide had been reduced to a fresh supply of sulphur and hydrogen for the active sites. From the literature, it is evident that the moderate pore size of NiMo-S, NiMo and $\mathrm{Pt}-\mathrm{Pd} / \gamma-$ $\mathrm{Al}_{2} \mathrm{O}_{3}-\mathrm{H}-\beta$ catalysts can control the secondary cracking [29]. Langmuir adsorption isotherms is used to investigate different materials are indicated in Figure 1, in which the hydroprocessing study of Pt-Pd/ $\gamma$ $\mathrm{Al}_{2} \mathrm{O}_{3}-\mathrm{H}-\beta$ reduces the pore diameter of $69.6 \AA$ to $44.3 \AA$. The result of lower coke deposition in Pt-Pd/ $\gamma-\mathrm{Al}_{2} \mathrm{O}_{3}-\mathrm{H}-\beta$ was an indication of a lower rate of deactivation and also, the selectivey and yield indicator of the HDO can be used as the study for the catalyst performance. 

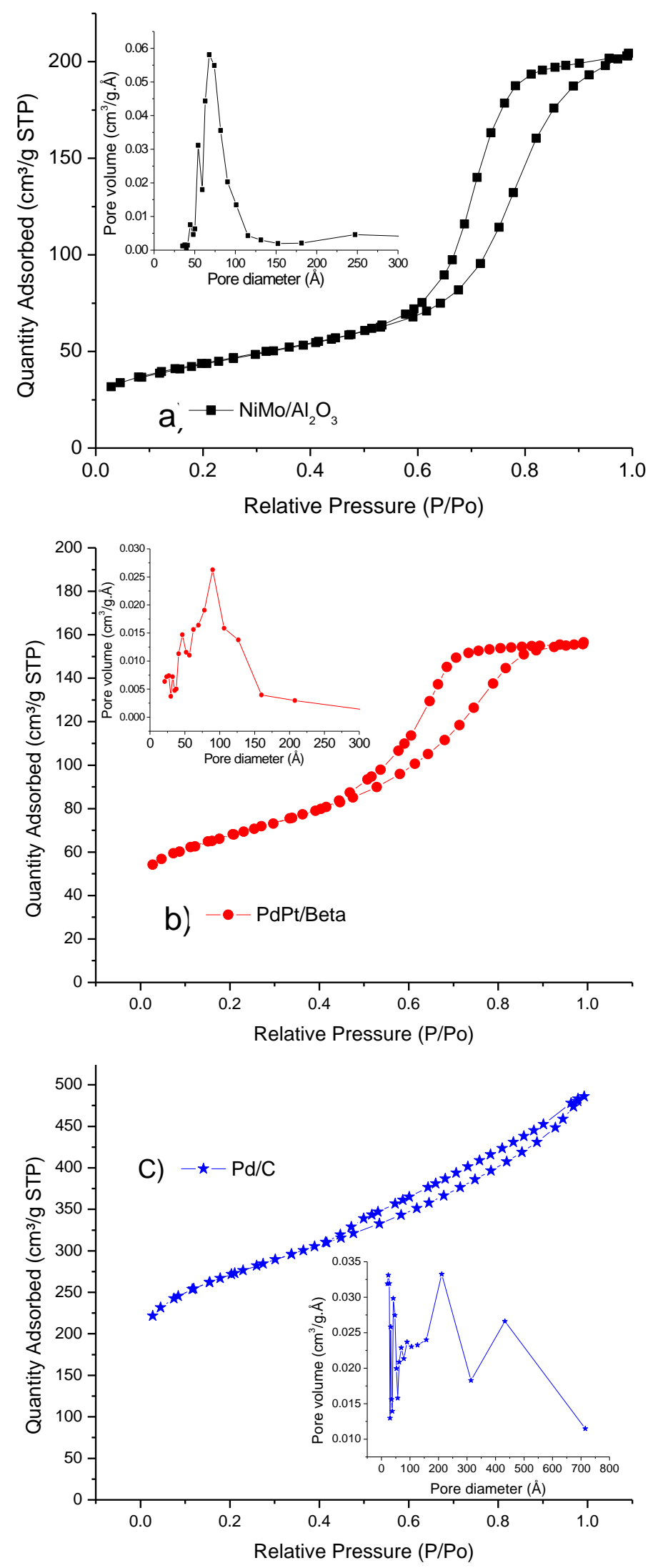

Figure 1. Surface area and pore volume characterization of the fresh catalysts

a) $\mathrm{NiMo}-\mathrm{S} / \mathrm{Al}_{2} \mathrm{O}_{3}$, b) Pt-Pd/ $\gamma-\mathrm{Al}_{2} \mathrm{O}_{3}-\mathrm{H}-\beta$ and c) $\mathrm{Pd} / \mathrm{C}$ (Note: $\mathrm{NiMo} / \mathrm{Al}_{2} \mathrm{O}_{3}$ and b) $\mathrm{PdPt} /$ Beta are denoted for NiMo-S/Al ${ }_{2} \mathrm{O}_{3}$ and $\mathrm{Pt}-\mathrm{Pd} / \gamma-\mathrm{Al}_{2} \mathrm{O}_{3}-\mathrm{H}-\beta$ in graphical representation) 


\subsection{Oxygenated products}

The study examined over triglycerides hydrogenation and HDO using NiMo, NiMo-S, Pd/C and Pt$\mathrm{Pd} / \gamma-\mathrm{Al}_{2} \mathrm{O}_{3}-\mathrm{H}-\beta$, which are carried out at $320^{\circ} \mathrm{C}$ and $2.0 \mathrm{MPa}$, either in the absence or presence of $\mathrm{H}_{2}$. As there are different materials with different shapes and structures in these catalyst studies, it is required to identify the minimum mass transfer resistance [32]. So, the effect of mass transfer resistance on the external catalyst surface can be determined by performing different temperatures and sterrier speeds. The conversion rate for $3 \mathrm{~h}$ run in batch reactor, for $20 \mathrm{wt} \%$ vegetal oil (20-SVO) in n-dodecane solvent of $320^{\circ} \mathrm{C}$ and $2.0 \mathrm{MPa}$ shows identical product formation at $650 \mathrm{rpm}$ to $1000 \mathrm{rpm}$. The sterrier speed of $700 \mathrm{rpm}$ is used for all the test-run with understanding of negligeble external diffusion, which has not influence the rate-controlling step. Also, under similar condition, hydrogenolysis of SVO is investigated. In this examining, for $10^{\circ} \mathrm{C}$ raise in operating temperature (between 300 and $35^{\circ} \mathrm{C}$ ), it tends to double the HDO conversion rate. This indicates the negeligible pore diffusing effect over the catalyst surface $[31,32]$.

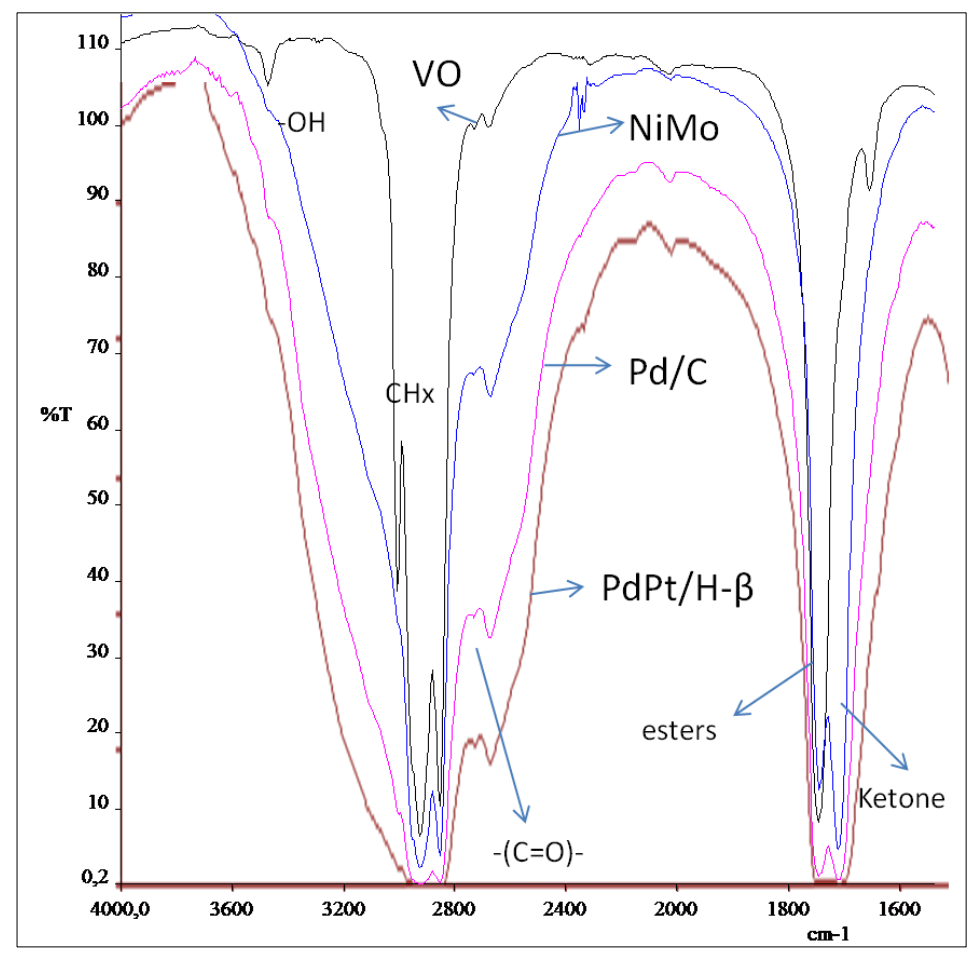

Figure 2. FTIR analysis of hydroprocessing pure sunflower oil samples with (NiMo)NiMo-S/ $\mathrm{Al}_{2} \mathrm{O}_{3}, \mathrm{Pd} / \mathrm{C}$ and

$\mathrm{Pt}-\mathrm{Pd} / \gamma-\mathrm{Al}_{2} \mathrm{O}_{3}-\mathrm{H}-\beta$ at $\mathrm{T}=320{ }^{\circ} \mathrm{C}$ and $2.0 \mathrm{MPa}$ (residence time $60 \mathrm{~min}$ )

The formation of oxygenated compounds, such as esters, carboxylic acids, aldehydes or ketones in OLP, appeared by the dissociation of $-\mathrm{C}-\mathrm{O}-$ in glycerides and $-\mathrm{C}-\mathrm{O}-(\mathrm{CO})-$ into free fatty acid/aldehydes and glycerol [15-20]. Figure 2 and 3 at FTIR transmission mode indicate the functional group apperaed in the OLP. 


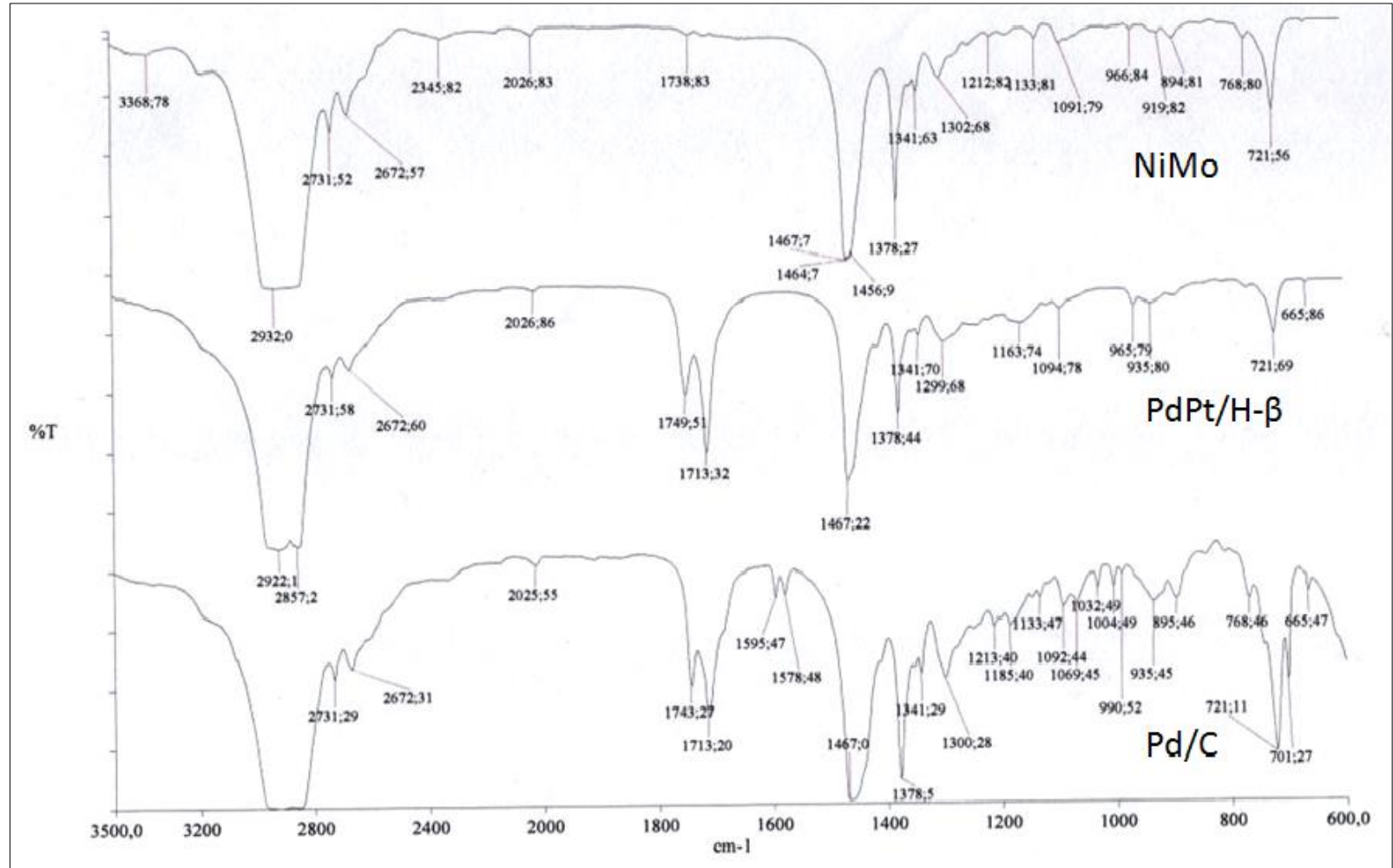

Figure 3. FTIR analysis of hydroprocessed 20-SVO after distilled (at operating condition: $\mathrm{T}=320^{\circ} \mathrm{C}, \mathrm{P}=2.0 \mathrm{MPa}$ and $100 \%$ conversion of triglycerides) samples taken on residence time in semi-batch reactor: $\mathrm{NiMo}=150 \mathrm{~min}, \mathrm{Pt}-\mathrm{Pd} / \gamma-\mathrm{Al}_{2} \mathrm{O}_{3}-\mathrm{H}-\beta=120 \mathrm{~min}$ and $\mathrm{Pd} / \mathrm{C}=150 \mathrm{~min}$

The FTIR result (Figures 2 and 3) observes that the aldehydes and alcohol formation shows an increase in concentration, at a wavelength between $2800 \mathrm{~cm}^{-1}$ and $3100 \mathrm{~cm}^{-1}$, which mainly shows the $\mathrm{CH}_{\mathrm{X}}$ level of the fatty ester group by HDO. A wavelength of about $3200 \mathrm{~cm}^{-1}-3400 \mathrm{~cm}^{-1}$ shows the presence of carboxyl acids $(-(\mathrm{C}=\mathrm{O})-\mathrm{OH})$ or alcohol $(\mathrm{O}-\mathrm{H})$ or water molecules. The wavelength around $2731 \mathrm{~cm}^{-1}$ shows the formation of aldehyde or ketone group and a peak at $1713 \mathrm{~cm}^{-1}-1715 \mathrm{~cm}^{-1}$ wavelength shows the presence of carboxyl acids or carbonyl compounds, represented in $\mathrm{C}=\mathrm{O}$ stretching. The wavelength peak at $1748 \mathrm{~cm}^{-1}-1742 \mathrm{~cm}^{-1}$ in catalytic hydroprocessing indicates the formation of esters and a peak at $920 \mathrm{~cm}^{-1}$ indicated the appearance of the aromatic and dimer group. Here, the radicals of carboxylic esters could form dimer compounds and it can be confirmed at the wavelength of $1280 \mathrm{~cm}^{-1}$ and an increase in $\mathrm{C}=\mathrm{C}$ stretch at $1650 \mathrm{~cm}^{-1}$, as observed in Figure 3. The dimers from the polymerisation of the carboxyl group show high concentration intensity for $\mathrm{Pd} / \mathrm{C}$, but other catalysts show only traceable amount. The band identified functional groups are listed in Table 2 based on using studies carried by Tegou et al [33].

Table 2. Characterization of notable band assignment in OLP from catalytic treatment with thermal decomposition as the wavelength collected from Figures $3 \& 4$ and its band identification.

\begin{tabular}{|c|c|c|c|c|}
\hline \multicolumn{4}{|c|}{ Wave length $\left(\mathrm{cm}^{-1}\right)$} & \multirow[t]{2}{*}{ Band assignment } \\
\hline NiMo-S & $\mathrm{Pd} / \mathrm{C}$ & $\begin{array}{l}\mathrm{Pt}-\mathrm{Pd} / \gamma- \\
\mathrm{Al}_{2} \mathrm{O}_{3}-\mathrm{H}-\beta\end{array}$ & $\begin{array}{l}\text { Thermal } \\
\text { cracking }\end{array}$ & \\
\hline $\begin{array}{r}2932 \\
2731,1467\end{array}$ & $\begin{array}{r}2922 \\
2731,1467\end{array}$ & $\begin{array}{r}2922 \\
2731,1467\end{array}$ & 2730 & $\begin{array}{l}\text { Symmetric and asymmetric stretching } \\
\text { vibration of the aliphatic } \mathrm{CH}_{2} \text { group, alkenes }\end{array}$ \\
\hline 2672 & 2672 & 2672 & 2800 & aldehyde $\mathrm{C}-\mathrm{H}$, acids $\mathrm{O}-\mathrm{H}$ (very broad) \\
\hline 1738 & 1749 & 1743 & - & $\begin{array}{c}\mathrm{C}=\mathrm{O} \text {, aliphatic esters, ester carbonyl } \\
\text { group }\end{array}$ \\
\hline 1341 & $\begin{array}{l}1713, \\
1341\end{array}$ & $\begin{array}{l}1713, \\
1341\end{array}$ & 1710 & $\mathrm{C}=\mathrm{O}$ stretching, $-\mathrm{COOH}$, Free fatty acids \\
\hline - & $\begin{array}{l}1595 \\
1578\end{array}$ & - & $\begin{array}{l}1595 \\
1578\end{array}$ & $\mathrm{C}=\mathrm{C}$ (in ring) ( 2 or 3 bands), arenes \\
\hline
\end{tabular}




\begin{tabular}{|ccccc|}
\hline 1378 & 1378 & 1378 & - & Bending vibrations of $\mathrm{CH}_{2}$ groups \\
1302 & 1299 & 1300 & - & C-O (alcohol) \\
1091 & 1092, & 1163, & - & C-O stretching $(\alpha-$ hydroxyl), stretching \\
& 1069 & 1094 & - & vibration of the C-O ester groups \\
- & 1032 & - & - & C-O stretching $(\beta$-hydroxyl) \\
trans- $\mathrm{R}-\mathrm{CH}=\mathrm{CH}-\mathrm{R}{ }^{\prime}$ \\
966 & - & 965 & 966 & $\mathrm{CH}_{2}$ rocking \\
919, & 939,721 & 939,721 & - & Arenes \\
721 & 701 & - & - & cis-R-CH=CH-R \\
- & 665 & 665 & - & \\
- & &
\end{tabular}

To understand thermal cracking in the catalytic hydrotreating technology, a non-catalytic thermal treatment needs to be carried out. Thermal cracking of 20 -SVO triglycerides at $320{ }^{\circ} \mathrm{C}$ and $2.0 \mathrm{MPa}$ in $\mathrm{N}_{2}$ atmosphere is investigated and table 2 represents the identified major spectroscopy peak. The wavelength of $1710 \mathrm{~cm}^{-1}$ indicates the carbonyl structure, either $-(\mathrm{CO}) \mathrm{H}$ or $-(\mathrm{CO})-$. Also, the wavelength of $2730 \mathrm{~cm}^{-1}$ implies the aldehydes or ketones, which show a broader spectrum indication. These broadband wavelengths of $2730 \mathrm{~cm}^{-1}$ and $1710 \mathrm{~cm}^{-1}$ show the formation of carboxyl acids that was due to the $\alpha$-carbon bond dissociation from the propane group. The FTIR result shows that wavelength from $3010 \mathrm{~cm}^{-1}$ to $2800 \mathrm{~cm}^{-1}$ has a broad intensity as noticed in Figure 3 . This more widespread intensity denotes the presence of a high concentration of glycerol or hydroxyl group, because of $\mathrm{CH}_{\mathrm{x}}$ scission between $\alpha$ - and $\beta$-carbon in glyceride ester. The $\mathrm{C}-\mathrm{O}$ bond of glyceride breaks at low enthalpy by leaving aldehyde or acid, or by leaving the both. In the $\mathrm{Pd} / \mathrm{C}$ hydrotreatment, the intensity in the OLP sample at $1595 \mathrm{~cm}^{-1}$ and $1578 \mathrm{~cm}^{-1}$ indicates aromatic/cyclic compounds. These arene compounds formation from the coupling of $\alpha$-carbon radical and carbonyl group are either formed from ester or propane dissociation in glycerides. The aromatic/cyclic compounds, as indicated by the wavelength of $1032 \mathrm{~cm}^{-1}$ and $701 \mathrm{~cm}^{-1}$, confirmed the presence of $\beta$-hydroxyl carbonyl compounds. Table 2 reports the band assignment in OLP and the carboxylic and carbonyl compounds for all the tested catalysts that had resembled in HDO product formation and also its reaction route. Table 2 and Figure 3 show the presence of trans- and cis- hydrocarbon chain. $\mathrm{PdPt} / / \gamma-\mathrm{Al}_{2} \mathrm{O}_{3}-\mathrm{H}-\beta$ has the strong and moderate intensity of trans- and cis- hydrocarbon, NiMo-S has only strong intensity at $966 \mathrm{~cm}^{-1}$ indicating trans-alkenes and $\mathrm{Pd} / \mathrm{C}$ has strong intensity at $665 \mathrm{~cm}^{-1}$ reporting cis-alkenes, whereas thermal cracking of trans-alkenes are observed on strong intensity at $966 \mathrm{~cm}^{-1}$, however, in the presence of $\mathrm{H}_{2}$ at thermal cracking induces in cis-alkenes formation.

It is found that the products from thermal treatment initiate bond breaking on esters. The breakage of the - $\mathrm{C}-\mathrm{O}-$ bond, either on the glycerol or ester chain can be expected. Primarily, the thermal vibration over the $\mathrm{C}-\mathrm{C}$ bonding initiates the decomposition of the saturated structure rather the unsaturated group. So, $\mathrm{C}=\mathrm{O}$ and $\mathrm{C}=\mathrm{C}$ has the stability on high bond energy [34] and inhibits secondary cracking on the saturated group; this implies that the catalytic activity can induce the carbonyl or pi-bonding at the active sites. The $\alpha$-carbon had weak stability and had low bonding energy, when compared to the $\beta$-carbon with its adjacent, so $\beta$-carbon can withstand the bond breaking to its adjacent of $\alpha$-carbon and $\gamma$-carbon compounds, as also mentioned in [35]. Thus, the expected bond break in $\alpha$-carbon can produce radicals which can saturate its valence using abstraction of $-\mathrm{H}$ atom from near-by carbon or in the hydrocarbon chain. This abstraction induces the unsaturation in the hydrocarbon between $\mathrm{C}_{3}$ and $\mathrm{C}_{15}$ carbon chains, and this can also initiate aromatic or cyclic compound formation.

\subsection{Hydrogenation and Hydrogenolysis}

In $\mathrm{H}_{2}$ atmosphere, pure SVO and 20-SVO in a semi-batch reactor are tested at $320^{\circ} \mathrm{C}$ and $2.0 \mathrm{MPa}$ by NiMo-S, $\mathrm{Pd} / \mathrm{C}$ and $\mathrm{PdPt} / / \gamma-\mathrm{Al}_{2} \mathrm{O}_{3}-\mathrm{H}-\beta$ catalysts. Here, the sampling of SVO hydroprocessed has tested with ${ }^{1} \mathrm{H}-\mathrm{NMR}$, which indicated the formation of hydrocarbons of $\mathrm{C}_{17}$ and $\mathrm{C}_{18}$ in hydroprocessing. This can be noticed in Figure 4. The peak identified ${ }^{1} \mathrm{H}-\mathrm{NMR}$ at $2.5-3 \mathrm{f} 1(\mathrm{ppm})$ for glycerides are disappeared in the OLP. It is revealed that the hydrogenation of the triglycerides formed, initially. Dissociation of carboxyl compounds initiates, and further the formation of saturated $\mathrm{C}_{17}$ and $\mathrm{C}_{18}$ hydrocarbons can be proved as the desired products of glycerides hydrogenolysis. 


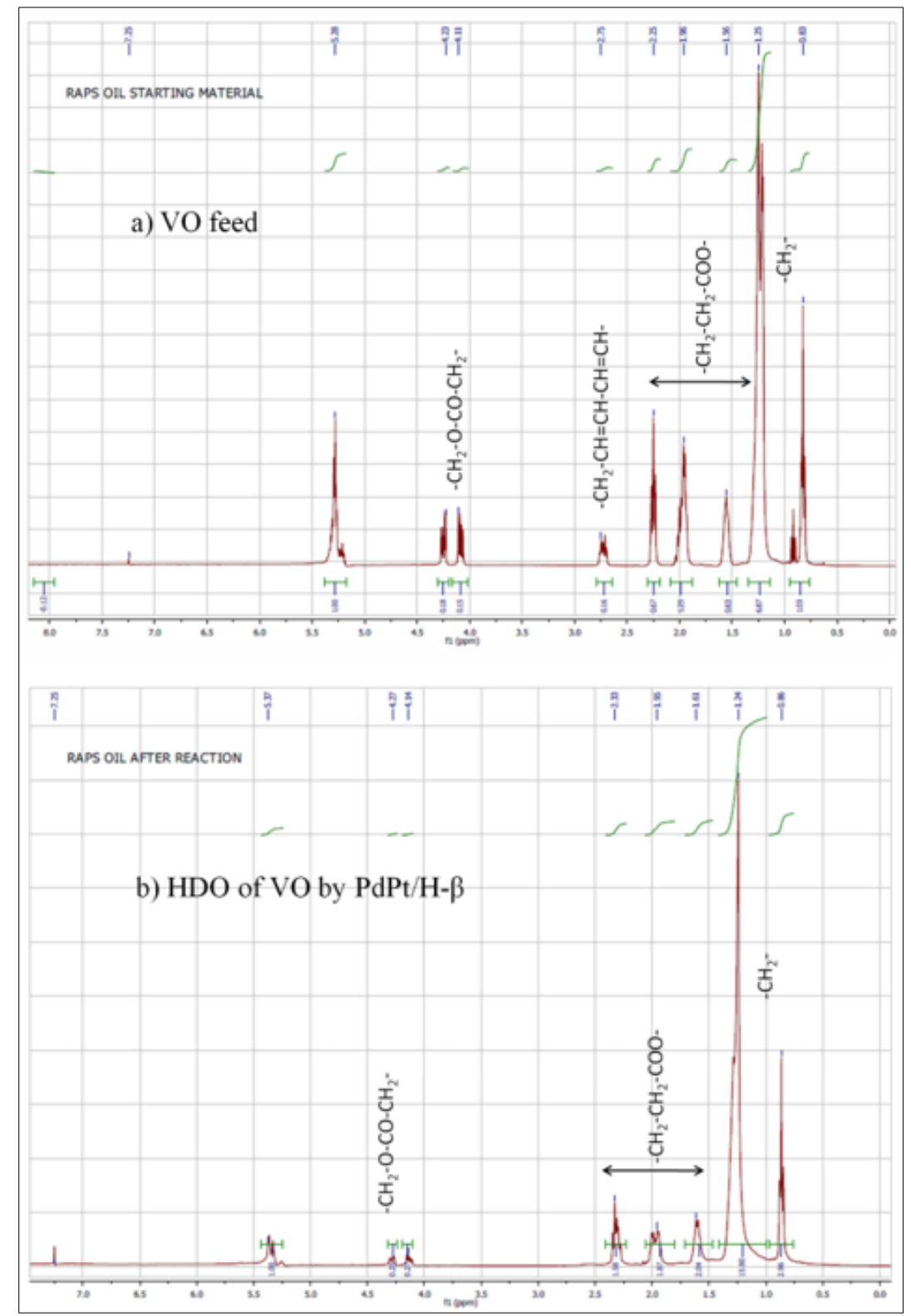

Figure 4. $1 \mathrm{H}-\mathrm{NMR}$ spectra (300 $\mathrm{MHz}$ for $1 \mathrm{H})$ of a) feed $\mathrm{SVO}$ and $\mathrm{b}) \mathrm{SVO}$ hydroprocessed using Pt-Pd/ $\gamma-\mathrm{Al}_{2} \mathrm{O}_{3}-\mathrm{H}-\beta$ at $\mathrm{T}=320{ }^{\circ} \mathrm{C}$ and $2.0 \mathrm{MPa}$ for $120 \mathrm{~min}$

The composition of carboxylic compounds in the intermediates using $\mathrm{Pd} / \mathrm{C}$ and $\mathrm{Pt}-\mathrm{Pd} / \gamma-\mathrm{Al}_{2} \mathrm{O}_{3}-\mathrm{H}-\beta$ catalytic process shows a side reaction in the formation of esters, carbonyl, carboxylic and lighter hydrocarbons (less than $\mathrm{C}_{8}$ ) in the OLP, as shown in the Figure 5 and 6 . But, SVO HDO by NiMo-S shows the highest yield in obtaining $\mathrm{C}_{17}$ and $\mathrm{C}_{18}$ hydrocarbons with minor quantity of carbonyl compounds. Product selectivity is reduced due to a low partial pressure of $\mathrm{H}_{2}$ in the involvement of $-\mathrm{H}$ protonation in the deoxygenation mechanism. Metal loaded on the catalyst was mainly beneficial for proton donor of DCA/DCO. While substituting of $-\mathrm{H}$ donor on HDO for carbonyl compounds results in the formation of water molecules and hydrogenolysis compounds such as (both saturated and unsaturated) $\mathrm{C}_{18}$. The abstraction of $-\mathrm{H}$ from hydrocarbon gives additional protonation on metal sites [7, 11]. But, lower electrophilicity on Ni metal over Mo, results in favour of HDO rather than direct scission of $(\mathrm{C}=\mathrm{O})-\mathrm{O}$ and $\mathrm{C}=\mathrm{O}$ bonds. Further sulphides improved the deoxygenation by metal effects, 
like $\mathrm{Ni}$ dispersion, and they gains direct deoxygenation with high selective compounds in hydroprocessing.
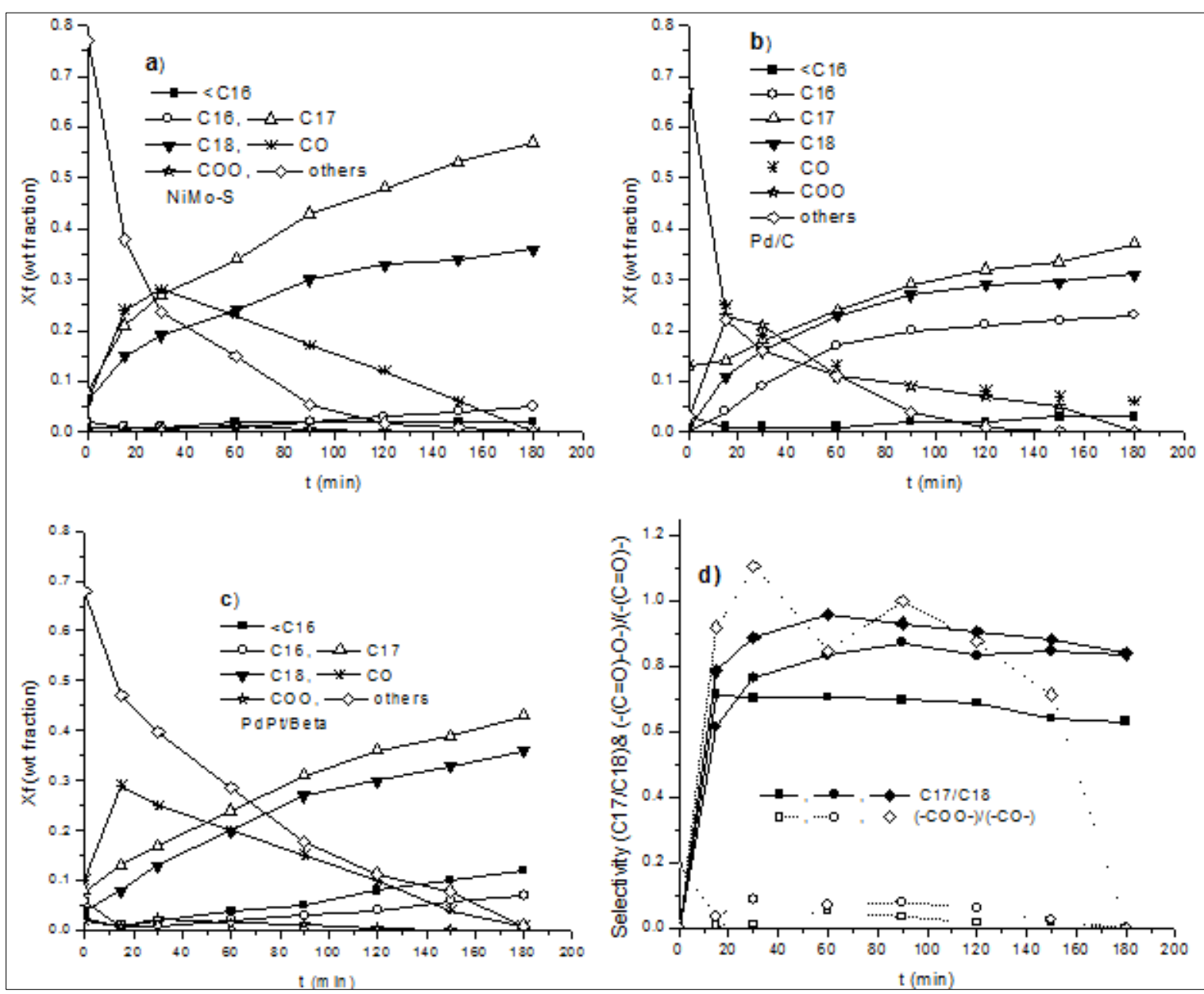

Figure 5. Concentration profile of OLP from hydroprocessing sunflower oil at $320^{\circ} \mathrm{C}$,

2.0 MPa with a) NiMo-S, b) Pd/C, c) Pt-Pd/ $\gamma-\mathrm{Al}_{2} \mathrm{O}_{3}-\mathrm{H}-\beta$ catalyst and d) Selectivity of $\mathrm{C}_{17} / \mathrm{C}_{18}$ and carboxylic acid (-COOH-)/carbonyl aldehyde (-CO-) represented as $\square$ \& $\square-\mathrm{NiMo}-\mathrm{S}, \circ \& \bullet-\mathrm{Pd} / \mathrm{C}$ and $\checkmark \& \diamond-\mathrm{Pt}-\mathrm{Pd} / \gamma-\mathrm{Al}_{2} \mathrm{O}_{3}-\mathrm{H}-\beta$. (Note: PdPt/Beta denoted as $\mathrm{Pt}-\mathrm{Pd} / \gamma-\mathrm{Al}_{2} \mathrm{O}_{3}-\mathrm{H}-\beta$ ).

(lines are drawn to guide eye)

In using $\mathrm{PtPd} / \mathrm{H}-\beta$, the formation of both straight- chain and branched $\mathrm{C}_{17}$ and $\mathrm{C}_{18}$ from hydrogenating carbonyl compounds are noticed. The deoxygenation associated with branching of hydrocarbon can be expected for hydroprocessing with the support of zeolite. Similarly, this branching can confirm with the higher unsaturated gases hydrocarbon such as $\Sigma \mathrm{C}_{3}, \Sigma \mathrm{C}_{4}$ and $\Sigma \mathrm{C}_{5}$ mentioned in the Figure 6. However sulfur-free catalyst of $\mathrm{Pt}-\mathrm{Pd} / \gamma-\mathrm{Al}_{2} \mathrm{O}_{3}-\mathrm{H}-\beta$ has weak acidity to undergo for deoxygenation with proton donor of $-\mathrm{H}$ atoms and the role on surface area and specific hydrogenation metals induces hydrogenolysis. This hydrogenation and hydrogenolysis are the primary reaction mechanism involved in hydrotreating and, collectively, this catalytic and thermal hydrotreating undergones hydroprocessing in the production of renewable diesel. 


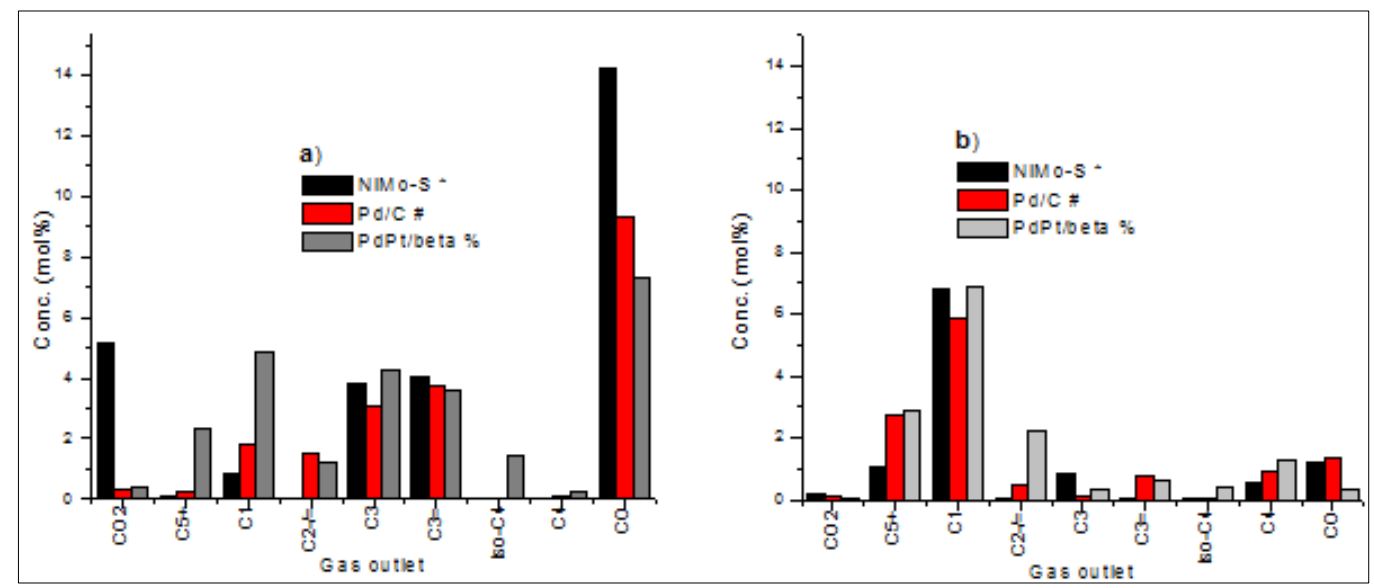

Figure 6. Concentration profile of gas outlet at $\mathrm{T}=320^{\circ} \mathrm{C}, 2.0 \mathrm{MPa}$, with

(*)NiMo-S, (\#)Pd/C and (\%) Pt-Pd/ $\gamma-\mathrm{Al}_{2} \mathrm{O}_{3}-\mathrm{H}-\beta$ catalyst for hydroprocessing a) sunflower oil and b) methyl oleate (Note: $\mathrm{PdPt} / \mathrm{Beta}$ denoted as $\mathrm{Pt}-\mathrm{Pd} / \gamma-\mathrm{Al}_{2} \mathrm{O}_{3}-\mathrm{H}-\beta$ )

\subsection{Catalytic hydroprocessing of triglycerides}

The hydroprocessing of the triglycerides with saturated and unsaturated $\mathrm{C}_{18}$ compounds examined at temperature $320^{\circ} \mathrm{C}$ and $2.0 \mathrm{MPa}$ represented in Figure 5. The notable results in Figure 5 shows that the formation of intermediate such as carboxylic acid $\left(\mathrm{C}_{17}-\mathrm{COOH}\right)$, ketones and aldehydes $\left(\mathrm{C}_{17}-\mathrm{CO}-\right)$. So, this intermediate produces $\mathrm{C}_{17}$ and $\mathrm{C}_{18}$ saturated hydrocarbons. Figure $5 \mathrm{~b}$ indicates the actual product distribution in OLP for $\mathrm{Pd} / \mathrm{C}$ hydroprocessing. The decomposition of $\mathrm{C}_{17-} \mathrm{COOH}$ or $\mathrm{C}_{17}-\mathrm{CHO}$ formed $\mathrm{C}_{16}$ and $\mathrm{C}_{17}$ in the OLP with partial hydrogenation and, this by-product can produce $\mathrm{CO}, \mathrm{CO}_{2}$, methane $\left(\mathrm{C}_{1}\right)$ and ethane/ene in the gas outlet. The total concentration of $\mathrm{CO}, \mathrm{CO}_{2}, \mathrm{C}_{1}$ and ethane/ene have produced 20, 13.5 and $14 \mathrm{~mol} \%$ at gas outlet through decomposition mechanism in NiMo-S, Pd/C and $\mathrm{Pt}-\mathrm{Pd} / \gamma-\mathrm{Al}_{2} \mathrm{O}_{3}-\mathrm{H}-\beta$, has been observed in Figure $6 \mathrm{a}$. Also, the same condition at $\mathrm{MO}$ has produced total concentration of $\mathrm{CO}, \mathrm{CO}_{2}$ and ethane/ene are $2.44 \mathrm{~mol} \%, 2.26 \mathrm{~mol} \%$ and $2.27 \mathrm{~mol} \%$, has been observed in Figure $6 \mathrm{~b}$. These results confirm the $\mathrm{C}-\mathrm{C}$ cracking of $\alpha$ - and $\beta$-carbon at fatty acids. The $\mathrm{CO}$ and $\mathrm{CO}_{2}$ in DCO and DCA mechanism evolved from hydrotreating of glycerides and it can also reduce the cetane value of diesel [36].
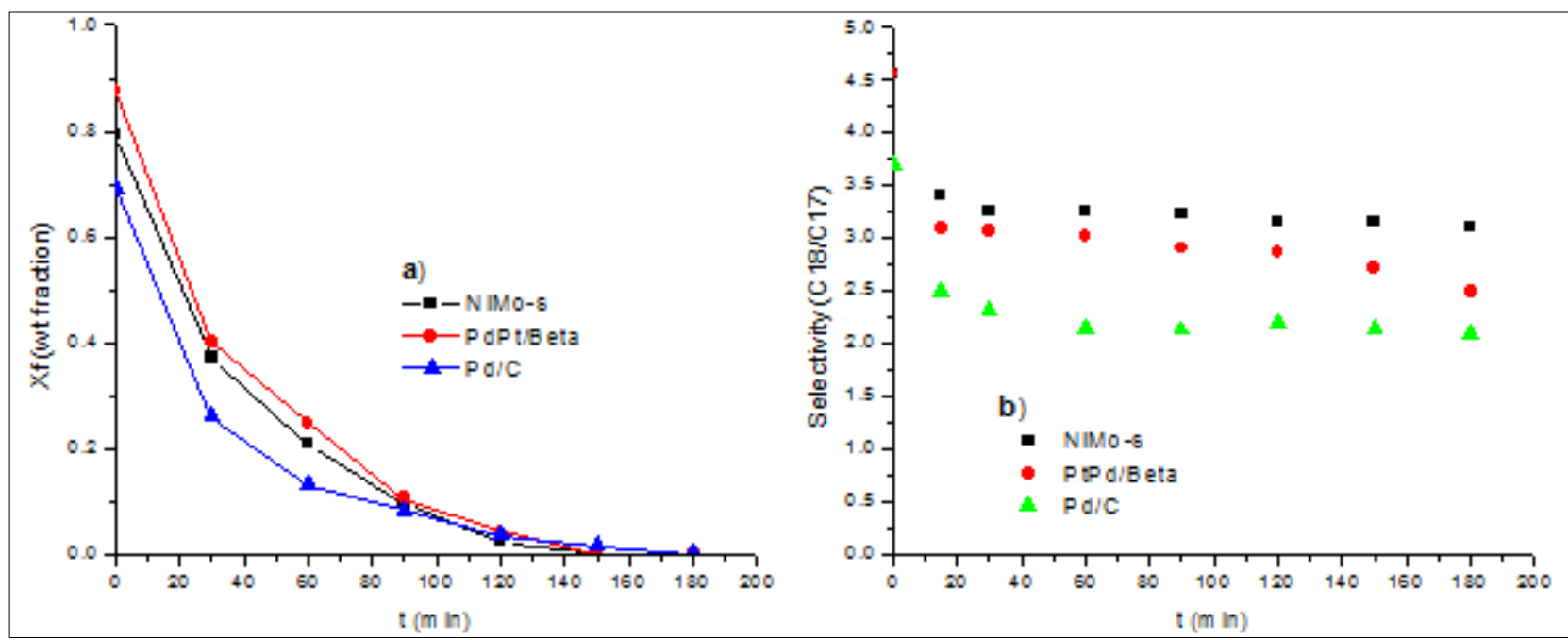

Figure 7. Product from $\mathrm{HDO}$ of MO in OLP sample at $\mathrm{T}=320{ }^{\circ} \mathrm{C}$ and $2.0 \mathrm{MPa}$ for Catalytic hydroprocessing: a) disappearance of $\mathrm{MO}$ and $\mathrm{b}$ ) selectivity of $\mathrm{C}_{18} / \mathrm{C}_{17}$. Note: $\mathrm{PdPt} /$ Beta denoted as Pt-Pd/ $\gamma-\mathrm{Al}_{2} \mathrm{O}_{3}-\mathrm{H}-\beta$. (lines are drawn to guide the eye) 
The HDO of NiMo-S, Pd/C and Pt-Pd/ $\gamma-\mathrm{Al}_{2} \mathrm{O}_{3}-\mathrm{H}-\beta$ have produced propane/ene from $\mathrm{SVO}$, as the compositions of gases $8.2,7.1 \mathrm{~mol} \%$ and $8.1 \mathrm{~mol} \%$, while methane from $\mathrm{MO}$ gives the compositions of 7.0, $6.2 \mathrm{~mol} \%$ and $7.1 \mathrm{~mol} \%$. The hydrogenation of $\mathrm{CO}$ and $\mathrm{CO}_{2}$ into $\mathrm{C}_{1}$ might happen in fuel gas of hydrotreatment. Using Pt-Pd/ $\gamma-\mathrm{Al}_{2} \mathrm{O}_{3}-\mathrm{H}-\beta$, the hydrogenation of $\mathrm{CO}$ and $\mathrm{CO}_{2}$ to $\mathrm{C}_{1}$ can attain hydrogenation at a low temperature over lower thermodynamically equilibrium condition. This driving mechanism might also enable the hydrogenation of $\mathrm{CH}_{3}-\mathrm{COOH}$ and $\mathrm{CH}_{3}-\mathrm{CHO}$ into ethane/ene. However, the selectivity of $\mathrm{C}_{17} / \mathrm{C}_{18}$ mole ratio from triglycerides through both NiMo-S and $\mathrm{Pd} / \mathrm{C}$ relatively appears between 0.7 and $0.85 ; \mathrm{Pt}-\mathrm{Pd} / \gamma-\mathrm{Al}_{2} \mathrm{O}_{3}-\mathrm{H}-\beta$ can produce 0.95 as indicated in the Figure $5 \mathrm{~d}$. Similar comparison of results on the mol ratio selectivity of carboxylic to carbonyl hydrocarbon indicates the NiMo-S and $\mathrm{Pd} / \mathrm{C}$ below 0.2 , but $\mathrm{Pt}-\mathrm{Pd} / \gamma-\mathrm{Al}_{2} \mathrm{O}_{3}-\mathrm{H}-\beta$ shows nearly 1.1 . The DCO and DCA mechanism in hydroprocessing produces $\mathrm{C}_{17}$, whereas the rate of this mechanism on NiMo-S [7,11] and $\mathrm{Pt}-\mathrm{Pd} / \gamma-\mathrm{Al}_{2} \mathrm{O}_{3}-\mathrm{H}-\beta$ may reduce the moderate temperature. This result confirms the formation of free fatty acids as intermediate and has a higher rate of $\mathrm{C}_{18}$ formed over sulphur-free zeolite. In the case of carbonyl group from glycerides, it induces higher decomposition to form $\mathrm{C}_{17}, \mathrm{CO}$ and $\mathrm{CO}_{2}$, thus the selectivity of $\mathrm{C}_{17} / \mathrm{C}_{18}$ had lower value for NiMo-S and Pd/C. Especially, $\mathrm{Pd} / \mathrm{C}$ has a higher rate of DCA and DCO reaction, which form low $\mathrm{C}_{18}$ hydrocarbons. With a lower selectivity ratio of $\mathrm{C}_{17}$ and $\mathrm{C}_{18}$, the cetane value can be enhanced in renewable diesel. Figure 7a points out that the rate of disappearing of triglycerides was higher for $\mathrm{Pd} / \mathrm{C}$ than other catalysts. But, its product selectivity is 20 to $30 \%$ lower than NiMo-S and Pt-Pd/ $\gamma-\mathrm{Al}_{2} \mathrm{O}_{3}-\mathrm{H}-\beta$, respectively, and this value can be observed in Figure $7 \mathrm{~b}$ and Table 3. As compared to NiMo-S, Pt-Pd/ $\gamma-\mathrm{Al}_{2} \mathrm{O}_{3}-\mathrm{H}-\beta$ has received $7 \%$ to $10 \%$ lower product selectivity in OLP, which indicates the branching of hydrocarbon tend to secondary cracking to form smaller fragment hydrocarbon. This hydrocarbon may not produce oligomeric products at the $\alpha$-carbon of any hydrocarbon chain, for both OLP of 20-SVO and MO. Hence, in disproportion mechanism, product hydrocarbon contain branches have been suitable for diesel compounds if its carbon chain within in its composition and boiling point ranges has became an advantage. So, as indicate in Table 3 , it indicates that the OLP have the formation of isomeric compounds using $\mathrm{Pt}-\mathrm{Pd} / \gamma-\mathrm{Al}_{2} \mathrm{O}_{3}-\mathrm{H}-\beta$ which is beneficial for fuel properties. Also, the low concentration of cyclic and aromatic compounds noted in zeolite HDO. But, the hydroprocessing of oxygenated hydrocarbon might need higher residence time for the complete hydration. So, it is necessary to have complete hydroprocessing with smaller flow velocity of direct SVO in continuous process.

Table 3. Hydroprocessing 20-SVO with different catalysts, at $\mathrm{T}=340{ }^{\circ} \mathrm{C}$ and $40 \mathrm{bar}$.

(Residence time in batch reactor for $120 \mathrm{~min}$ )

\begin{tabular}{|c|c|c|c|c|c|c|c|c|}
\hline \multirow[b]{2}{*}{ Products } & \multicolumn{4}{|c|}{ SVO (wt\%) } & \multicolumn{4}{|c|}{ MO (wt\%) } \\
\hline & $\begin{array}{l}\mathrm{NiMo} / \\
\mathrm{Al}_{2} \mathrm{O}_{3}\end{array}$ & $\begin{array}{c}\mathrm{NiMoS} / \mathrm{A} \\
\mathrm{l}_{2} \mathrm{O}_{3}\end{array}$ & $\mathrm{Pd} / \mathrm{C}$ & $\begin{array}{c}\mathrm{PtPd} / \gamma- \\
\mathrm{Al}_{2} \mathrm{O}_{3}-\mathrm{H}- \\
\beta \\
\end{array}$ & $\begin{array}{l}\mathrm{NiMo} / \\
\mathrm{Al}_{2} \mathrm{O}_{3}\end{array}$ & $\begin{array}{l}\mathrm{NiMoS} \\
/ \mathrm{Al}_{2} \mathrm{O}_{3}\end{array}$ & $\mathrm{Pd} / \mathrm{C}$ & $\begin{array}{c}\mathrm{PtPd} / \gamma- \\
\mathrm{Al}_{2} \mathrm{O}_{3}-\mathrm{H}- \\
\beta\end{array}$ \\
\hline$<\Sigma \mathrm{C}_{16}$ & 0.7 & 0 & 0.4 & 4.7 & 2.3 & 0.1 & 0 & 2.9 \\
\hline$\Sigma \mathrm{C}_{17}$ & 1.6 & 10.8 & 9.3 & 5.1 & 3.1 & 8.2 & 8.9 & 5.3 \\
\hline$\Sigma \mathrm{C}_{18}$ & 0.3 & 7.8 & 6.9 & 3.2 & 3.7 & 11.7 & 7.9 & 4.8 \\
\hline$\Sigma \mathrm{C}_{17-} \mathrm{CHO}$ & 3.5 & 1.4 & 2.7 & 4.4 & 4.3 & 0.1 & 3.1 & 6.4 \\
\hline$\Sigma \mathrm{C}_{17}-\mathrm{COOH}$ & 2.5 & 0.1 & 0.5 & 1.8 & $* *$ & $* *$ & $* *$ & $* *$ \\
\hline$\Sigma \mathrm{C}_{18}-\mathrm{OH}$ & 0 & 0 & 0.1 & 0 & $* *$ & $* *$ & $* *$ & $* *$ \\
\hline$\%$ Conv. & 42.8 & 99.5 & 99.5 & 96.1 & 67.3 & 99.4 & 99.5 & 97.2 \\
\hline
\end{tabular}

Initially, the hydroprocessing of SVO in the presence of $\mathrm{H}_{2}$ has involved in the hydrogenation, rather than the effect of hydration, which happens if the saturation effectively consumes $\mathrm{H}_{2}$. So, the rate of deoxygenation slows down due to weak $-\mathrm{H}$ proton density on the surface of active sites or inadequate $\mathrm{H}_{2}$ supply through the gas film. However, the presence of $-\mathrm{H}$ proton on transition metals can suppress the dehydrogenation mechanism. So, suppressed dehydrogenation can critically affect the initiation of 
branching of the carbenium ions. But, in this study, the $-\mathrm{H}$ proton deficiency enhances the dehydrogenation and increases the carbenium formation. So, this mechanistic rate of hydrogenation and dehydrogenation can increase the carbocation and secondary cracking. In addition to partial hydrogenation, cracked hydrocarbon can consume $\mathrm{H}_{2}$. In this case of reduced $-\mathrm{H}$ proton for longer residence time, the decrease in the slope of selectivity can be identified due to the catalyst proton deficiency, which is observed in Figure 7b. Hence, it increases the rate of dissociation, either the dehydrogenation from alcohol or DCO of carbonyl group into $\mathrm{C}_{17}$ and $\mathrm{CO}$ or $\mathrm{CO}_{2}$.

\section{Conclusions}

This study reveals that $\mathrm{C}_{18}$ and $\mathrm{C}_{17}$ are the final products in hydroprocessing of all sulphide and nonsulphide catalysts, excluding high concentration of $\mathrm{C}_{16}$ formation in $\mathrm{Pd} / \mathrm{C}$. NiMo-S can achieve high catalytic activity and selectivity; instead, the use of NiMo can initiate DCA and DCO pathways only. The reduction of $\mathrm{H}_{2}$ partial pressure involves in deactivation either by $-\mathrm{S}$ rupture on active sites or reduced dehydration with no proton supply in the HDO mechanism. So, $\mathrm{H}_{2}$ consumption for hydrogenation of unsaturated glyceride ester group is notable for all tested catalysts. The unsaturated SVO contains mainly cis-group esters, which can be converted into trans-group esters. Multilayer adsorption over $\mathrm{Pd} / \mathrm{C}$ catalyst involved in $\alpha$ - and $\beta$-carbon cracking as the intrinsic mass transfer control on the surface for desorption might break of the molecules into lighter hydrocarbon. Also, DCA and DCO can be extended to higher order in thermal dissociation due to smaller pore volume. Langmuir IVtype adsorption isotherm of catalysts such as NiMo-S and Pt-Pd $/ \gamma-\mathrm{Al}_{2} \mathrm{O}_{3}-\mathrm{H}-\beta$ has enhanced $\mathrm{HDO}$ with higher pore volume, which can give better selectivity in $\mathrm{C}_{17}$ and $\mathrm{C}_{18}$ formation. However, $\mathrm{Pt}-\mathrm{Pd} / \gamma-\mathrm{Al}_{2} \mathrm{O}_{3}-$ $\mathrm{H}-\beta$ resembles in the reaction rate with NiMo-S and forms relatively similar coke deposition and deactivation. Also, branching of carboxylic and carbonyl compounds in hydroprocessing through Pt$\mathrm{Pd} / \gamma-\mathrm{Al}_{2} \mathrm{O}_{3}-\mathrm{H}-\beta$ is beneficial, but higher temperature can induce the equilibrium and increases the decomposition at a disproportion route to make hydrocarbon branching such as isomerisation and oligomerisation.

Acknowledgments: We thank Dr. Borje S. Gevert for experimental support and special thanks to Preem $\mathrm{AB}$, Sweden, for sample analysis.

\section{References}

1.DRAGOMIR, R.E., ROSCA, P. Biofuel from Hydroprocessing Fish Oil, Rev. Chim., 71(1), 2020, 176185

2.JAMES, O.O., MAITY, S., MESUBI, M.A., USMAN, L.A., AJANAKU, K.O., SIYANBOLA, T.O., A review on conversion of triglycerides to on-specification diesel fuels without additional inputs, International Journal of Energy Research, 36(6), 2012, 691-702.

3.SANKARANARAYANAN, T.M., BERENGUER, A., OCHOA-HERNÁNDEZ, C., MORENO, I., JANA, P., CORONADO, J.M., Hydrodeoxygenation of anisole as bio-oil model compound over supported Ni and Co catalysts: Effect of metal and support properties, Catalysis Today, 243, 2015, 163 172.

4.PALANISAMY, S., GEVERT, B.S., SANKARAN, P., KANDASAMY, K., Produce low aromatic contents with enhanced cold properties of hydrotreated renewable diesel using Pt/alumina-beta-zeolite: Reaction path studied via mono-aromatic model compound, Energies, 12, 2019, 2853.

5.LIU, C., LIU, J., ZHOU, G., TIAN, W., RONG, L., A cleaner process for hydrocracking of jatropha oil into green diesel, Journal of the Taiwan Institute of Chemical Engineers, 44, 2013, 221-227.

6.PALANISAMY, S., GEVERT, B.S., Hydroprocessing of fatty acid methyl ester containing resin acids blended with gas oil, Fuel Processing Technology, 126, 2014, 435-440.

7.PALANISAMY, S., GEVERT, B.S., Study of non-catalytic thermal decomposition of triglyceride at hydroprocessing condition, Applied Thermal Engineering, 107, 2016, 301-310. 
8.SHELDON, R.A., Green chemistry, catalysis and valorization of waste biomass, Journal of Molecular Catalysis A: Chemical, 422, 2016, 3-12.

9.TOBA, M., ABE, Y., KURAMOCHI, H., OSAKO, M., MOCHIZUKI, T., YOSHIMURA, Y., Hydrodeoxygenation of waste vegetable oil over sulfide catalysts, Catalysis Today, 164(1), 2011, 533537.

10.ASIKIN-MIJAN, N., LEE, H.V., ABDULKAREEM-ALSULTAN, G., AFANDI, A., TAUFIQYAP, Y.H., Production of green diesel via cleaner catalytic deoxygenation of Jatropha curcas oil, Journal of Cleaner Production, 167, 2017, 1048-1059.

11.PALANISAMY, S., GEVERT, B.S., Hydrodeoxygenation of fatty acid methyl ester in gas oil blendNiMoS/alumina catalyst, Green Processing and Synthesis, 7(3), 2018, 260-267.

12.FURIMSKY, E., Hydroprocessing challenges in biofuels production, Catalysis Today, 217, 2013, 13-56.

13.KORDULIS, C., BOURIKAS, K., GOUSI, M., KORDOULI, E., LYCOURGHIOTIS, A., Development of nickel based catalysts for the transformation of natural triglycerides and related compounds into green diesel: a critical review, Applied Catalysis B: Environmental, 181, 2016,156-196. 14.HANCSÓK, J., KRAR, M., MAGYAR, S.Z., BODA, L., HOLLÓ, A., KALLO, D., Investigation of the production of high quality biogasoil from pre-hydrogenated vegetable oils over Pt/SAPO-11/Al $\mathrm{O}_{3}$, Studies in Surface Science and Catalysis, 170, 2007, 1605-1610.

15.ARORA, P., OJAGH, H., WOO, J., GRENNFELT, L.E., OLSSON, L., CREASER, D., Investigating the effect of Fe as a poison for catalytic HDO over sulfided NiMo alumina catalysts, Applied Catalysis B: Environmental, 227, 2018, 240-251.

16.SIMACEK, P., KUBICKA, D., SEBOR, G., POSPISIL, M., Hydroprocessed rapeseed oil as a source of hydrocarbon-based biodiesel, Fuel, 88(3), 2009, 456-460.

17.JENISTOVA, K., HACHEMI, I., MÄKI-ARVELA, P., KUMAR, N., PEURLA, M., CAPEK, L., Hydrodeoxygenation of stearic acid and tall oil fatty acids over Ni-alumina catalysts: Influence of reaction parameters and kinetic modelling, Chemical Engineering Journal, 316, 2017, 401-409.

18.BUZETZKI, E., SIDOROVA, K., CVENGROSOVA, Z., KASZONYI, A., CVENGROS, J., The influence of zeolite catalysts on the products of rapeseed oil cracking, Fuel Processing Technology, 92(8), 2011, 1623-1631.

19.WANG, H., YAN, S., SALLEY, S.O., NG, S.K.Y., Support effects on hydrotreating of soybean oil over NiMo carbide catalyst, Fuel, 111, 2013, 81-87.

20.KROBKRONG, N., ITTHIBENCHAPONG, V., KHONGPRACHA, P., FAUNGNAWAKIJ, K., Deoxygenation of oleic acid under an inert atmosphere using molybdenum oxide-based catalysts, Energy Conversion and Management, 167, 2018, 1-8.

21.ZHANG, W., YE, Z., ZHAO, L., WEI, W., Catalytic Activities of NiMo Carbide Supported on $\mathrm{SiO}_{2}$ for the Hydrodeoxygenation of Ethyl Benzoate, Acetone, and Acetaldehyde, Energy \& Fuels, 24(3), 2010, 2052-2059.

22.SINHA, A.K., SIBI, M.G., NAIDU, N., FAROOQUI, S.A., ANAND, M., KUMAR, R., Process Intensification for Hydroprocessing of Vegetable Oils: Experimental Study, Industrial \& Engineering Chemistry Research, 53(49), 2014, 19062-19070.

23.ZHAO, Y., PRINS, R., Mechanisms of hydrodenitrogenation of alkylamines and hydrodesulfurization of alkanethiols on $\mathrm{NiMo} / \mathrm{Al}_{2} \mathrm{O}_{3}, \mathrm{CoMo} / \mathrm{Al}_{2} \mathrm{O}_{3}$, and $\mathrm{Mo} / \mathrm{Al}_{2} \mathrm{O}_{3}$, Journal of Catalysis, 229(1), 2005, 213-226.

24.LIU, J., LEI, J., HE, J., DENG, L., WANG, L., FAN, K., Hydroprocessing of Jatropha Oil for Production of Green Diesel over Non-sulfided Ni-PTA/ $\mathrm{Al}_{2} \mathrm{O}_{3}$ Catalyst, Scientific Reports, 5, 2015,11327.

25.WANG, F., JIANG, J., WANG, K., ZHAI, Q., SUN, H., LIU, P., Activated carbon supported molybdenum and tungsten carbides for hydrotreatment of fatty acids into green diesel, Fuel, 228, 2018,103-111. 
26.WANG, C., LIU, Q., SONG, J., LI, W., LI, P., XU, R., High quality diesel-range alkanes production via a single-step hydrotreatment of vegetable oil over Ni/zeolite catalyst, Catalysis Today, 234, 2014, 153-160.

27.SRIFA, A., FAUNGNAWAKIJ, K., ITTHIBENCHAPONG, V., ASSABUMRUNGRAT, S., Roles of monometallic catalysts in hydrodeoxygenation of palm oil to green diesel, Chemical Engineering Journal, 278, 2015, 249-258.

28.SÁNCHEZ, M.J.F., BOLDRINI, D.E., TONETTO, G.M., DAMIANI, D.E., Palladium catalyst on anodized aluminum monoliths for the partial hydrogenation of vegetable oil, Chemical Engineering Journal, 167(1), 2011, 355-361.

29.LUP, K.A.N., ABNISA, F., WAN DAUD, W.M.A., AROUA, M.K., A review on reactivity and stability of heterogeneous metal catalysts for deoxygenation of bio-oil model compounds, Journal of Industrial and Engineering Chemistry, 56, 2017, 1-34.

30.SATYARTHI, J.K., CHIRANJEEVI, T., GOKAK, D.T., VISWANATHAN, P.S., An overview of catalytic conversion of vegetable oils/fats into middle distillates, Catalysis Science \& Technology, 3(1), 2013, 70-80.

31.CHEN, H., ZHANG, X., ZHANG, J., WANG, Q., Tuning the decarboxylation selectivity for deoxygenation of vegetable oil over Pt-Ni bimetal catalysts via surface engineering, Catalysis Science \& Technology, 8(4), 2018, 1126-1133.

32.AKYALCIN, S., Kinetic study of the hydration of propylene oxide in the presence of heterogeneous catalyst. Chem. Ind. Chem. Eng. Q. 2017;23(4):573-580.

33.VLACHOS, N., SKOPELITIS, Y., PSAROUDAKI, M., KONSTANTINIDOU, V., CHATZILAZAROU, A., TEGOU, E., Applications of Fourier transform-infrared spectroscopy to edible oils, Analytica Chimica Acta, 573-574, 2006, 459-465.

34.OSMONT, A., YAHYAOUI, M., CATOIRE, L., GÖKALP, I., SWIHART, M.T., Thermochemistry of $\mathrm{CO},(\mathrm{CO}) \mathrm{O}$, and $(\mathrm{CO}) \mathrm{C}$ bond breaking in fatty acid methyl esters, Combustion and Flame, 155(1), 2008, 334-342.

35.OSMONT, A., CATOIRE, L., GÖKALP, I., SWIHART, M.T., Thermochemistry of C-C and C-H Bond Breaking in Fatty Acid Methyl Esters, Energy \& Fuels, 21(4), 2007, 2027-2032.

36.LI, D., XIN, H., DU, X., HAO, X., LIU, Q., HU, C., Recent advances for the production of hydrocarbon biofuel via deoxygenation progress, Science Bulletin, 60(24), 2015, 2096-2106.

Manuscript received: 18.04 .2020 